\title{
Environmental trust? Sustainability and renewables policy and practice in the school years
}

\author{
John Buchanan ${ }^{1}$ (D) \\ Received: 10 August 2020 / Revised: 29 November 2020 / Accepted: 7 December 2020 / Published online: 18 January 2021 \\ (C) Australian Curriculum Studies Association 2021
}

\begin{abstract}
The mobilisation of young people is an essential part of attempts to mitigate the effects of climate change. This position paper investigates matches and mismatches between sustainability education policy, curriculum and practice, by examining associated literature and policy documents, including syllabuses. The paper adopts a "policy cycle approach" lens through which to examine the process from policy to practice, and potential credibility gaps therein. One dynamic emergent in the literature is mistrust, which manifests in several forms in the policy-practice process. Education bureaucracies are perceived as placing little confidence in teachers, resulting in relatively rigid policy and syllabus documents. Similarly, such bureaucracies might be mistrusted by some practising teachers, while global oganisations, such as the United Nations, are mistrusted by many lay people, serving to compromise credibility in the resulting curricular and policy documents. The paper focuses on Australia, but also refers to international contexts as relevant. It notes some promising pedagogies, and proposes some recommendations for practice.
\end{abstract}

Keywords Environmental sustainability education $\cdot$ Sustainability curriculum $\cdot$ Sustainability policy $\cdot$ Trust

\section{Introduction}

The wellbeing of the planet and its people hinges on crucial decisions concerning sustainable futures. Arguably, foremost among these is a reduction in carbon emissions, to minimise global warming and its effects. Nowotny et al. (2018) assert "the imperative [is] to aggressively decarbonize the energy economy and develop new technologies, especially for the generation of electrical energy that are environmentally clean" (p. 2541).

The imperative for sustainability education is ever-increasing, given escalating (in)human planetary impact, through increased population, and technologies that are more environmentally intrusive in their production, application and disposal. Martin et al. (2013) establish the mandate for sustainability education, highlighting three premises: unsustainable resource depletion, inequality of resource access and use and education as critical in addressing the aforementioned two dynamics. Cars and

John Buchanan

john.buchanan@uts.edu.au

1 University of Technology Sydney, 15 Broadway, Ultimo, NSW 2007, Australia
West (2015) contend, "education plays a catalytic role in conscientizing citizens in current and future societies" ( $\mathrm{p}$. 16 , emphasis in original).

This position paper invokes relevant literature, including policy documents and syllabuses, to depict some features of the contextual landscape in which sustainability education operates, and the potential for mistrust, misunderstanding and conflict of purpose among policy-makers and teacher-practitioners. The paper then examines Australian and other sustainability education policy documents, before exploring selected related curricula. Subsequently, the paper illustrates some relevant sustainability education practices, before drawing some conclusions.

Various terms co-exist to describe this field, including education for sustainability (EfS), environmental education (EE) and environmental sustainability education (ESE). This paper will adopt "sustainability education", its environmental context being implicit. The scope of this paper prohibits a lengthy discussion of definitions; I draw here on Jacobs' (1993) definition, which enfolded interdependent consideration of environmental and economic factors, commitment to social justice, including fair resource sharing, and a view of development incorporating quality of life. 


\section{Contextual background}

Sustainability education faces numerous challenges if it is to avert habitat loss in school curricula. Among the foremost is a retreat to basic skills, that can lead to a timidity in teaching (Buchanan 2020), which might find expression in an avoidance of topics deemed controversial, such as global warming and energy transition management. Jorgenson et al. (2019) reviewed related sustainability education literature. They noted a gap between studying climate change and energy, with only 16 of the 70 papers reviewed (23\%) discussing energy transitions.

Focusing on basic skills can displace sustainability education (Barnes et al. 2018). However, the choice between basic skills, and developing the skills, knowledge and will to protect, prolong and promote the planet's capacity to provide everyone's needs, need not be so binary. Newmann et al. (2001) examined over 9000 Chicagoan year 3-8 student assignments, controlling for socio-economic status and language background. They concluded, "if teachers, administrators, policymakers and the public ... place more emphasis on authentic intellectual work in classrooms, early gains on standardized tests in Chicago could surpass national norms" (p. 2). Similarly, in a broader US context, Chapman (2009) asserts, "green schools can save money, improve health, and boost academic achievement" (p. 2, emphasis added). Sahlberg (2012) refers to a current global pandemic, GERM, the Global Education Reform Movement. He observes, "it travels with pundits, media and politicians. Education systems borrow policies from others and get infected. As a consequence, schools get ill, teachers don't feel well, and kids learn less". The symptoms of GERM, including curricula armed with high-stakes tests, are likely to constrain the creative, courageous, critical and lateral thinking needed to address local and global environmental problems, locally and globally.

Local and international environmental crises, while costly, have focussed many minds. While some proclaim "business as usual" following the 2019-2020 Australian bushfires, others have begun questioning earlier assumptions (Lockie 2020). Accordingly, climate anxiety has emerged as a substantive youth issue (Ojala 2016). While this may prompt action, one should avoid overwhelming young people with the enormity of the problem, but rather remind them of their potential collective and collaborative agency in such matters, alongside reminders that decarbonisation of the economy is already afoot (Wade and Griffiths 2020).

Covid-19 has arguably precipitated and impeded sustainability education. Its immediate consequences, health-wise and economic, have probably displaced climate change concerns somewhat. Conversely, the pandemic has exposed numerous chinks in our self-sufficiency, and may impel us to address this, individually and nationally. This, alongside issues of long-term cost, and the physical and mental wellbeing deriving from blue skies and clean air, may hasten the adoption of, for example, solar panels or public transport.
Poorly articulated policy can result in dissonance with practice. In a context of sustainability education in the UK, Martin et al. (2013) report a "loss of policy coherence across government and ... mixed messages and confusion for many of those in formal and non-formal education contexts" (p. 1536). This will be reprised in the policy section. Much goodwill prevails among teachers for sustainability education (Barnes et al. 2018), but related teaching might retreat to the superficial. This will be discussed under sustainability in practice.

\section{Method}

This study draws on three main data sources. The findings and discussion derive from a wide-ranging review of literature on education about climate change and managing the transition to renewable energy. While the review centres on Australia, other examples are included, for their implications for a trustecology. Education policy documents, and associated curricula, are also analysed for intent concerning transitioning from fossil fuels. Finally, examples of promising practice are enumerated and discussed, drawn from educational jurisdictions and some professional associations. The approach has some elements in common with grounded theory (Strauss and Corbin 1994). The theme of trust emerged from preliminary readings of the literature. This manifested in two ways: the need for trust, and for trustworthiness; and a current reserve in according trust, which, itself, might be a product of a more educated, critically literate, population. Accordingly, some limits of trust are discussed.

The lens through which policy and practice are examined is informed by Ball's (2012) cyclic theorisation of policy Lingard and Sellar (2013): refer to this as a "non-linear, interactive, multidirectional reality of policy as both text and process across three interactive contexts: the context of influence, the context of text production, and the context of practice" (p. 268), as part of what Ball (2012) referred to as "Global Education Inc" in light of increasing globalisation and creeping neo-liberalism.

\section{Findings and discussion}

This section examines policy, including education policy, syllabus documents, then sustainability education in practice, and possible gaps in this transformation, after Ball (1998). As Tilbury (1995) observed, "No document exists to date which translates the goals of EEFS [environmental education for sustainability] into guiding principles for its development in schools" (p. 195). This section will explore to what extent this persists. 


\section{Policy documents}

Education policy documents offer useful insights into the aspirations that elders harbour for young learners. A subtle dilution of agentic aspirations for Australian learners emerges over time. The Melbourne Declaration on goals for young Australians (MCEETYA 2008, p. 7) set out the following goal, that: "All young Australians become:

- successful learners

- confident and creative individuals

- active and informed citizens." (MCEETYA 2008, p. 7). This was recently superseded by the Alice Springs (Mparndwe) Declaration, wherein, "All young Australians become confident and creative individuals, successful lifelong learners, and active and informed members of the community" (Australian Government 2020, p. 5). The emphases are added to each quote, for comparison. "Members of the community" are arguably less threatening, more benign and more "docile bodies" (Ohara \& Buchanan, 2018) than are "citizens". Young people should be encouraged towards vocal criticality against what I'll call here, "government by hypocracy".

Numerous shortcomings manifest in developing and applying sustainability education policies. Smith and Stevenson (2017) identify three impediments to sustainability education in Australia: failure of policy to reflect international sustainability initiatives; fluctuating policy under changing governments, agendas and ideologies and "policy competition". Aikens et al. (2016) reviewed 215 sustainability education policy research papers, and reported the following five key findings: spasms of policy output over the four decades of their review, the most recent of which coinciding with the United Nations' Decade of Education of Sustainable Development; geographic imbalance of policy output, with underrepresentation from the developing world; a preponderance of non-empirical studies; absence of policy responding to climate change and a higher proportion of studies on teacher directives rather than policy development per se (p. 334).

The predominance of teacher directives is interesting, and reflects a more widespread deprofessionalision of, and mistrust in, teachers (Buchanan 2020). Moreover, as indicated earlier, adoption of documents such as the Sustainable Development Goals will be mediated by trust in their authority.

Another feature of policy is its limited capacity for selfcriticism, nuance or doubt. Nazir et al. (2009) noted that much sustainability policy documentation emanates from environmental or government organisations, and comprises, "selfreports ... uncritical catalogues that focus on successes, are silent about problems or failures" (p. 27). This might serve to sow seeds of doubt in such dicta. In a Taiwanese context, Tsai
(2011) is quite sanguine about the establishment of numerous policy documents and organisations to support sustainability education, but imprecise on their impact on school practice.

Much education policy is driven by non-educators (Buchanan 2020). Policy frequently falters in translation into practice. There is a regrettable schism between theorised practical application and problem-solving approaches to sustainability on the one hand, and a focus within school programs on the more easily testable acquisition of knowledge (Stevenson 2007a), arguably an example of assessment-driven pedagogy. Nevertheless, policy drives curriculum. Roberts and Downes (2016, pp. 29-30) refer to "curriculum-as-policy, with privileged values analogous to the role of policy in allocating values and resources", or what Orr $(1998$, p. 2) referred to as "an organizational level denial" of practice. Jorgenson et al. (2019) noted a lag in adopting associated action-oriented approaches in practice. They proposed a "a vision and strategy on climate change and energy education that more explicitly addresses the role of collective action, multiactor networks, and sociotechnical innovation in shaping energy transition processes" (p. 168).

This gap arguably precipitates policy fractures both with sustainability, and learning in general (Moore 2005). The gap establishes a dissonance: between theory and practice; and between engagement (to address problems) and obligation (to commit facts to memory). It is a socially safe, yet environmentally risky pathway. It propagates (Stevenson 2007a) "the uncritical role of schooling in maintaining the present social order" (p. 139). It is a cautious, controlled approach, a conservative strategy, which, regrettably, fails to conserve.

\section{Curriculum documents}

Curriculum, that is, policy-in-practice at system and school level, naturally, drives teaching and learning. As with policy documents, curriculum documents regularly aim aspirationally high. Australia's recently introduced national curriculum embodies three cross-curriculum priorities, including Sustainability (ACARA n.d.-b). Sustainability is organised around three key concepts: a systemic approach; worldviews, incorporating values, social justice and actions, and futures, focusing on capacities for thought and action. According to the Australian Curriculum (ACARA n.d.-a), "sustainability addresses the ongoing capacity of Earth to maintain all life". The document elaborates:

Sustainable patterns of living meet the needs of the present without compromising the ability of future generations to meet their needs. Actions to improve sustainability are individual and collective endeavours shared across local and global communities. They necessitate a renewed and balanced approach to the way humans interact with each other and the environment. 
However, while this is labelled an Australian Curriculum "priority", no assessable outcomes inhere to it. There is a risk, therefore, that teachers, faced with meeting the outcomes of an arguably crowded curriculum, and schools, burdened with improving literacy and numeracy scores for the benefit of public consumption (Ragusa and Bousfield 2017; Buchanan 2020), might clear-fell this priority for "the basics". The "crowded curriculum" can serve as a refuge for inattention to environmental sustainability at school. Jóhannesson et al. (2011) describe curriculum as "a site of contestation and compromise" (p. 385). And, of congestion, I would add, although this might be subsumed by Jóhannesson et al.'s "contestation". Again, though, Newmann et al.'s (2001) conclusion above, about authentic tasks and standardised tests, serves to address this; students could be offered, and required to produce, texts of substance, linked to the issues that concern their beyond-school lives. If relevance is a benchmark of quality educational activities, surely sustainability education meets this metric. Just as Ladson-Billings (1992, p. 3) advocated reading "between the lines and beyond the pages", students can be offered learning experiences that that extend to, and derive from, life outside school, and from which they can practise deriving between-the-lines inferences, for further consideration and scrutiny. And by definition, all education should deliver learners beyond their current visible horizons.

None of the above is to ascribe blame to either syllabus writers or teachers, but might it mean that they are working at cross (curricular) purposes? More broadly, increased accountability and associated league tables may impel teachers to seek refuge among "safe", uncontroversial topics and texts. Barnes et al. (2018) surveyed 116 teachers or school leaders in one Australian state, and concluded that sustainability remains untreated in cross-curricular fashion in Australian schools, being displaced by literacy and numeracy. They warn, "the lofty intent of the new Australian Curriculum cross-curricular priority of sustainability may remain largely unrealized" (p. 179). Similarly, Kennelly et al. (2012) see sustainability as "unconvincingly represented" in the Australian Curriculum (p. 209), and warn about its consequent "backward un-mapping" in teacher education courses. While this study focuses on schooling, teacher preparation is essential for quality sustainability education. Wilson (2012) investigated blockers and drivers of sustainability education, and identified lack of time as the most significant blocker. Emphasising the importance of sustainability education during pre-service is an effective way of raising and multiplying its profile and effects in schools and their communities. Barnes et al. (2018) claim that in the absence of teachers conceptualising sustainability in their own practice and context, curricular innovations such as those concerning sustainability will remain "voiceless in the classroom" (p. 391).

With reference to the state of New South Wales in Australia, sustainability resides most overtly in the
Geography Syllabus (NESA 2019a). Even at the upper end of the compulsory years (for students aged up to 15 or 16), the prescribed outcomes in the NSW Geography Syllabus tend to be rather "receptive" in nature: explains, analyses, accounts for, assesses, acquires, processes and communicates. While I understand that 16-year-olds are not professional geographers, there appear to be few opportunities for them to formulate and then test their ideas, by devising and assessing, analysing, amongst others. The most explicit invitation to suggest alternatives is perhaps in stage 5 , "analyses... ways to improve human wellbeing" (NESA 2019a). The document does not specify whether students are to analyse existing wellbeing approaches, and/or to propose their own for analysis. Moreover, "wellbeing" is likely to offend no one. This bears out Stevenson's (2007a) contention, above, of caution and control on the part of syllabus documents; control is antithetical to trust.

The above circumspection may stem from a disinclination to relinquish control and entrust young people with the agency (Bandura 2006) to enact positive change, and to support them accordingly. Ärlemalm-Hagsér and Davis (2014) compared Australian and Swedish early years curricula, observing limited scope for learner action or agency among these documents, which offer "narrower and weaker forms of education for sustainability" (p. 240). Whether abetted or not by school curricula, many young people are exercising environmental agency and autonomy through school strike movements and the like (Shine 2019).

As part of its rationale for the study of Human Society and its Environment (the forerunner of current History and Geography syllabuses), the Board of Studies, NSW (1998, p. 7) proclaimed, "The future wellbeing of human society and its environment depends on the quality of people's interactions with each other and with their cultural, social and physical environments as they strive to meet each other's needs". Education Scotland (2020) sets out the following descriptors for sustainability education: "a cross-curricular approach to creating coherent, rewarding and transformative learning experiences". It further outlines five strategic objectives for sustainability education, encompassing the entitlement of all learners; leadership in practice/practice in leadership; a "robust, demonstrable, evaluated" whole-school approach; resonance with policy, buildings and school grounds and strategic national support. In the NSW and Scottish aspirational documents, as an educator, and an inhabitant of planet earth, I find succour here (perhaps more than substance). And yet, their words give teachers and students licence to be transformed, to transform, to lead.

While sustainability education will likely find a more "natural habitat" (Buchanan 2012) in some subjects than others, it arguably resonates with every learning area, including crossdisciplinary and transdisciplinary studies. In particular, geography, science, English/literacy, civics and citizenship, and the arts lend themselves to understanding and communication of 
environmental concepts (see ACARA n.d.-a). While civics and citizenship finds a place in the Australian Curriculum (ACARA n.d.-c), it, too, is unaccompanied by assessable outcomes.

Rich tasks can nourish the intellect (Newmann et al. 2001). Sustainability education carries with it a well-fitting symbiosis with any or all of the following, some of which are to be found among the Australian Curriculum's general capabilities (ACARA n.d.-d): critical, creative and lateral thinking; personal and social responsibility; systems thinking and analysis; ethical understanding; (collaborative) problem-solving (and solution-problematising); action orientation and hands-onness; communication skills; understanding and interrogation of perspectives; project learning and service learning and question-answering (and answer-questioning), as well as the "threeRs". Sustainability addresses concepts embedded in local Geography and History syllabuses, including interconnection, continuity and change, cause and effect, empathy, perspectives, significance and contestability (NESA 2019b, c). As such, it is a trusty organiser for cross-curricular units of study, particularly in the formative, primary years (Taylor et al. 2013), where one teacher typically teaches all or most subjects. Further investigation into primary and secondary contexts is warranted.

Numerous jurisdictions have established frameworks or pathways to assist with sustainability education. With a view to encouraging students to act on energy consumption, the NSW Department of Education (NSW Government n.d.) adopts the Sustainability Action Process, comprising five phases: making the case; exploring; planning; taking action and reflecting. The project- and problem-based nature of this approach entrusts students to make a difference. The site contains learning resources for, inter alia, energy use and efficiency, for the primary and secondary years. The Ministry of Education in New Zealand (n.d.-a) has established a framework for a sustainable school, based on interplay among people, programs, place and practices. New Zealand's curriculum outlines a number of cross-curricular learning activities, including Chocolate: Fair trade and hauora (a Māori word referring to holistic health) (Ministry of Education, [New Zealand] n.d.-b). Such documents can be called on by teachers as a defence and vindication of pursuing sustainability education.

Sweden's Ministry of Education (2018) implemented a primary year curriculum in 2011 which entrusted young learners to assume responsibility for environmental issues locally, and to establish a personal position on global sustainability issues. It specified that, "teaching should illuminate how the functions of society and our ways of living can best be adapted to create sustainable development" (p. 8). Jóhannesson et al. (2011) developed a set of seven criteria by which to examine sustainability education in Iceland. These comprise, paraphrased here: values and emotions; knowledge requisite for sustainable resource use; wellbeing; global awareness and economics; participatory democratic equality and cultural inclusivity; (p. 375). The last of these is explicitly trust-encrusted. Jóhannesson et al. found that the Icelandic Curriculum offered "diverse but not obvious" entry points for environmental sustainability education (p. 383). As such, these opportunities might not be immediately identifiable to the unsearching eye. Jóhannesson et al. recognise that their own curricular examination was "a bold attempt to find in them opportunities for education for sustainable development" (p. 383). Martin et al. (2013) lament the lack in the UK of a "coherent view at policy or practice level about how ESD can most appropriately be experienced by learners, in a progressive sense" (p. 1537) in the school years and beyond. While this is a worthy quest, whose progressive nature appears to accord trust to learners, there is arguably no "most appropriate way". The following section discusses sustainability education practice.

\section{Sustainability education in practice}

Environmental care is not new. For millennia, indigenous peoples have practised, modelled and taught stewardship of/ responsibility for country (Beckford et al. 2010; JacksonBarrett and Lee-Hammond 2018; McCoy et al. 2016). In an Australian Indigenous context, "land links" are one of the "eight Aboriginal ways of learning" (Yunkaporta 2010, p. 40). In a Canadian context, Beckford et al. (2010) argue that "while not a panacea, Aboriginal environmental epistemologies hold lessons for teaching environmental stewardship and sustainability behavior in mainstream classrooms" ( $p$. 239). Similarly, Australia's recent bushfire disasters have precipitated a re-thinking of what can be learnt from customary Indigenous fire-control practices (Morgan et al. 2020). It is estimated that the fires emitted the equivalent of 830 million tonnes of $\mathrm{CO}_{2}$, and impaired the forests' carbon sink capacity (Department of Industry, Science, Energy and Resources, 2020). The resulting smoke circled the southern hemisphere (NASA 2020), killing more people than the fires themselves (Arriagada et al. 2020). In Australia, the concepts of learning on, from, and through, Country have recently (re)gained credibility (Fogarty and Schwab 2012; Country et al. 2014).

One feature of indigenous approaches to sustainability and land care is its comprehensive nature. Sustainability education does well to adopt a holistic approach, addressing the complex ecology of factors social, environmental and economic (Jóhannesson, et al. 2011), "a vital interconnected web of social, ecological and spiritual relationships" (Whitehouse et al. 2014, p. 58). As Cajete (1994, p. 78) proclaimed, "modern societies must recapture the ecologically sustainable orientation that has long been absent from its psychological, social and spiritual consciousness". Understandably, Indigenous students might be suspicious of colonial artefacts, 
such as official curricula, purporting to address environmental sustainability - to be graded by environmental degraders? Nor is environmental stewardship the exclusive preserve of Indigenous peoples; it has a sustained presence in industrial societies (e.g. Morgenstern 2007).

There appears to be a credibility gap between some lofty statements in flagship educational documents (e.g. the Melbourne Declaration and the Alice Springs Declaration, above, in Australia), and practice, including action-orientation. Jorgenson et al. (2019) discern some value in motivating individuals to modify their behaviour in the move towards renewable energy, but observe considerably more potential in harnessing collective associated action. As part thereof, they recommend maximising opportunities for interaction with key sector players, in research, science, philanthropy and business, for example, to introduce students to communities of practice, and in the hope of establishing sustained interaction with such bodies and their members, that will outlast the learner's school-life. Support for these ideals is at times wanting, however. In England, the Sustainable Schools Initiative aims to provide learning experiences that imbue young people with the desire and capacity to live sustainably (Bourne et al. 2016). The initiative encompasses eight thematic "doorways", including energy and water, and travel and traffic (Bourne et al. 2016, p. 23). The scheme lost government funding in 2010, and is now funded by Non Government Organisations. Chapman (2009) surveyed 1056 principals in 12 US states, and found good local practice, with nearly $40 \%$ of the surveyed schools having a "sustainability champion" on staff. He also identified, however, a need for a more concerted approach to sustainability education, and limited associated funding. The principals advocated (p. 3):

more money, time, and staff; better organization and designated leadership; greater commitment from the school board and district, an overall sustainability plan for their schools, and outside support; as well as more buy-in, enhanced staff training, and more integration of environmental education into curriculum at their schools.

While action orientation is noble, it should not proceed without understanding of causes and effects. Students can be relied upon to turn off lights and heaters if they understand the dynamics of global warming, and stop littering if they understand the effects of, for instance, plastic on sea life. Moreover, they will be better equipped to recruit others to do likewise, and can better refute others' objections to such proenvironmental behaviours. Extending this, as a perspectives exercise, it might be useful intellectually and pragmatically for students and teachers to consider and study how others around the world might be acting locally while thinking globally.
What might their community of sustainable practice look like, and how might it be similar to or different from mine?

Cars and West (2015) report some encouraging educational developments in Sweden, and focus on three at primary school level: "all-weather" outdoor schools, in which children gain hands-on experience in the natural environment; "schools for sustainable development distinction" and Green Flag schools (in collaboration with Denmark, Germany, Greece and the UK) (pp. 13-15). Wake and Eames (2013) investigated an action-oriented project in which primary school students constructed an eco-classroom. As part of their analysis of the process, Wake and Eames devised an "ecology of learning", with five characteristics, each nested within the former, and each interrelated: local inclusivity; an empathic community of practitioners; supportive school structures; skilled teacher facilitation and a student-centred learning focus (p. 311). One feature common to these programs is an implicit learnercentred focus of trust. In the US, Next Generation Science Standards (2020) embrace a holistic approach, encompassing three dimensions of learning: cross-cutting concepts between the sciences, science practice or method and core disciplinary ideas. Despite the "Standards" title, they strive to be descriptive rather than prescriptive, giving teachers leeway to develop their own pedagogical pathways towards meeting the standards.

Other examples of promising practices include NSW's Climate Clever Energy Savers (Buchanan et al. 2014) in which schools developed a proposal and applied to their state's Education Department for funds for its implementation. Proposals included the installation of solar panels, light switch timers and the like. Central to this project was the trust it placed in young people to devise solutions to identified local problems. Reverse Garbage (2018) is another example of programs that offer carbon-friendly alternatives to rubbish disposal.

An urban-rural mistrust also emerges from the literature. Those closest to the land, understandably, might not care for being lectured to by "city folk" — whose cities are fed, clothed, lit and warmed or cooled by local industries - about land management. Reasonably, they may be irritated by urban schoolteachers' and a curriculum's apparent non-acknowledgement of local knowledge capital and perspectives. Predominantly urban teachers might be eyed suspiciously in some rural areas (Roberts \& Downes 2016), particularly those whose local income derives from resource-intensive activities, such as mining or agriculture. Exacerbating this mistrust of "the bourgeois", poverty in rural communities is more extensive than in cities, particularly, but not exclusively, in the developing world (Tickamyer et al. 2017; World Bank 2020). This dynamic is perhaps aggravated by the fact that many teachers may find their first jobs in rural areas, leading to a dearth of experience in such schools (Schuck et al. 2016). For their part, children in urban areas also face problems regarding 
connections with the land. Having expanded our horizons over recent centuries, with increased options for travel, is it possible that our portals to the world might be currently contracting? Increasingly, we inhabit apartments, and, arguably, experience the world more vicariously, through screens (Louv 2005). While these screens can take us to worlds otherwise inaccessible or dangerous, they are not reliable substitutes for the touch of moss on tree, or snowflake on tongue, the humbling crack and pulse of lightning and thunder, the lulling, or fearsome roar, of ocean waves, the sense of humid air or breeze on skin, the rustle of spider, the scent of eucalypts, salt air or imminent rain. Devices have their place, however; travel to wilderness areas will entail its own environmental impact. Moreover, online learning modes have been found to generate positive relationships among participants, and with their instructor and the content ( $\mathrm{Li} \mathrm{et} \mathrm{al.} \mathrm{2016),} \mathrm{and} \mathrm{with} \mathrm{experts} \mathrm{in} \mathrm{the}$ field.

Evans et al. (2012) case-studied two rural north Queensland schools, and identified three categories of barriers, each more complex and intractable than the former: grassroots, administrative and conceptual (p. 124). They further identified six major specific barriers: funding; staff resistance; conceptual understanding; cultural resistance; leadership and trust (p. 128). The authors nominated enhanced trust and leadership as two particularly important considerations in any sustainability education initiative in such locations. Perhaps even more than in urban settings, teachers in rural schools might need to "act local and think global" to gain credibility and relevance in their sustainability approaches and initiatives. Hailing from elsewhere, these teachers may well invest trust in, and learn from, their students' commitment to and ownership of the local area, albeit with a critically eye. Any apparent "environmental loyalty" on teachers' part might otherwise appear hollow, pious and untrustworthy to students. As Hall et al. (2020) indicate, gaining the confidence of, through consultation with, local communities is an essential in managing energy transitions.

Nevertheless, it is those who live "on the land" who stand to benefit most immediately from its careful stewardship, and who will be the first to suffer if the land exhausts from overuse. As with any resource, there remains the temptation to overwork the land for short-term gain, regardless of, or in ignorance of, long-term consequences. Further research exemplifying current classroom and school-based practices would be valuable.

In summary, "conversations" between policy, syllabus and practice do not always appear coherent or mutually intelligible (Ball 1998; Lingard and Seller 2013). Stevenson (2007b, p. 265) calls for:

constructing discourses of professional learning that reflexively build, sustain and develop...spaces and opportunities for enacting meaningful environmental education in schools. Such a discourse and approach ... can move the focus from educators' implementation of environmental education (as expressed in the policy discourse) to building their normative and technical capacity, both individually and collectively, to shape practice.

\section{Conclusions and recommendations}

The data informing this paper have exposed a series of rifts between government rhetoric, government policy, education rhetoric, education policy, syllabuses, teacher practice and student engagement. Stevenson (2007b, p. 266) describes a rhetoric-practice gap, arguing that schools and teacher practice-in-context should be entrusted to exercise some influence over policy, as opposed to the current subordination of teacher practice to policy and rhetoric. Stevenson advocates,

the construction of a new discourse that, instead of viewing policy and practice as a 'top-down' or centreperiphery relationship, embraces a dialectic and dynamic relationship between goals and conceptual characteristics (typically encapsulated in policy discourse) on the one hand, and teaching and learning practices on the other-and with learning about one informing learning about the other. (p. 278)

In so doing, Stevenson disclaims perfection on the part of teacher practice, but contends that it would benefit from being informed by a two-way discourse with policy. Indeed, unquestioningly privileging "what-works" practice over policy could amplify the abovementioned dynamic of dismissing the expertise and experience of curriculum designers, some of whom are, or have been, teachers themselves. And yet, in this instance, teachers, too, are field experts. This process might include releasing teachers from the shackles of basic skills testing. Aikens et al. (2016) advocate a more critical approach to policy research, one which understands its complexity, and what I will refer to here as its "nocence"-its lack of innocence, or its capacity to do harm by omission or commission.

As noted above, Aikens et al. (2016) reported that UN policy tended to catalyse sustainability policy at national and local levels. This appears to have been the case again since the release of the UN's (n.d.) Sustainable Development Goals. Hopefully, schools and teachers might leverage such policy documents, and indeed current events, such as bushfires, and school climate strikes, and appropriate them pedagogically. Teachers might also like to underscore the potential savings associated with solar panels, and, more immediately, with 
switching off lights and appliances when not needed, as per the Climate Clever initiative referred to earlier (Buchanan et al. 2014). Advances in technology, such as improved batteries, as well as economies of scale, are likely to shift the balance towards renewables in terms of both cost and reliability, to save the environment from fossil-fuelled exhaust(ion). Students might wish to lobby politicians in this regard, seeking a just transition in subsidies from fossil to renewable fuels.

As a means of challenging mistrust in those who seek a cleaner, more sustainable future, environmental history could be studied in schools, wherein students investigate past sustainability initiatives and failures. Studies might focus on sites of unnatural disasters, such as Bhopal, Fukushima or Chernobyl, some of which have become eponyms for their respective calamities; a moment in time such as the last known thylacine; broader areas, such as the effects of introduced species including, in Australia, cane toads, rabbits and dingoes; or deforestation, or global warming, against a historic backdrop. Studies might explore related causes and effects, harm minimisation and means of future prevention, and might serve to mobilise young people to act to forestall future environmental cataclysm. Students might investigate policy and practice possibilities such as, rather than currently exporting "virtual water" (Hoekstra and Hung 2005) through crops grown and stock raised in semi-arid climes, Australian exports of "virtual sunshine" in solar panels.

One side-effect of Covid-19 appears to be "environmental convalescence" in response to a relatively short period of economic and industrial downturn (Colvin et al. 2020; ZambranoMonseratte et al. 2020). This seems to suggest that we can "have it all" or at least much of "it"-a healthy economy and healthy air, blue skies, clean rain - if we can just manage transition to renewable energy sources. As intimated above, an educated, politically active public will be crucial in realising this. It will rely upon the concerted effort of all education stakeholders: policymakers, curriculum writers, educational jurisdictions and teachers.

Making the related curriculum locally relevant, particularly for younger students, will likely pay dividends here. As Buchanan et al. (2018) note, "it may be that the curricular and assessment trees must bend to the breeze of student interest" in this regard (p. 5). Teachers, new to a school district, may need to apprentice themselves temporarily to the students and their local knowledge and allegiances to "their patch", in order to harness and direct their energies towards beneficent environmental goals. McKenzie (2012, p. 165) speaks of privileging "local 'good sense' over neoliberal global 'common sense" ". This may contradict standardised, one-size-fitsall jurisdictional curricula and policy (Buchanan 2017). It arguably serves governments' interests to produce a citizenry whose members do not complain too loudly, or in too informed a manner, about their planet and its stewardship. Locally sited, globally minded citizen science projects (see
Buchanan et al. 2018) may be one way of addressing this, while still meeting standards of scientific inquiry.

Jorgenson et al. (2019, p. 168) observe that:

Energy exerts and activists around the world are working to strengthen community, weaken corporate control, and resist fossil-fuel reliance because it contributes to a concentration of wealth and power in society as well as all the negative health, safety and environmental implications.

Trust in young people and their capacity and willingness to act might serve to neutralise some of the above dynamics. Jorgenson et al. continue:

Given the powerful educational opportunities associated with envisioning renewable-based society, new forms of $\mathrm{EE}$ are required that include opportunities for students to develop these visions and experience the fundamental struggles and structural changes involved in trying to enact them collectively.

Policy has arguably failed to change professional practice. Might personal, professional and collective action influence policy? It seems that changes in direction and policy and practice priorities are urgently needed if we are to have a planet that will "outlive the grandchildren". Science's strength lies in asking "why?" This aligns seamlessly with pursuing the whys and why nots of sustainability practice and policy, including use and sharing of resources. Stevenson (2007a, p. 278) calls on us to "learn our way forward" towards higher levels of sustainability. The policy-practice interface appears at times monologic, and not always "understood" by practitioners. "Trust" might well be stirred into policy-practice cycle or dialogue.

\section{References}

ACARA (n.d.-a). Sustainability. Retrieved from https://www. australiancurriculum.edu.au/f-10-curriculum/cross-curriculumpriorities/sustainability/.

ACARA (n.d.-b). Cross-curriculum priorities. Retrieved from https:// www.australiancurriculum.edu.au/f-10-curriculum/crosscurriculum-priorities/sustainability/.

ACARA (n.d.-c). Civics and citizenship. Retrieved from https://www. australiancurriculum.edu.au/f-10-curriculum/humanities-andsocial-sciences/civics-and-citizenship/.

ACARA (n.d.-d). General capabilities. Retrieved from https://www. australiancurriculum.edu.au/f-10-curriculum/general-capabilities/.

Aikens, K., McKenzie, M., \& Vaughter, P. (2016). Environmental and sustainability education policy research: a systematic review of methodological and thematic trends. Environmental Education Research, 22(3), 333-359. 
Ärlemalm-Hagsér, E., \& Davis, J. (2014). Examining the rhetoric: a comparison of how sustainability and young children's participation and agency are framed in Australian and Swedish early childhood education curricula. Contemporary Issues in Early Childhood, 15(3), 231-244.

Arriagada, N., Palmer, A., Bowman, D., Morgan, G., Jalaludin, B., \& Johnston, F. (2020). Unprecedented smoke-related health burden associated with the 2019-2020 bushfires in eastern Australia. Medical Journal of Australia. https://doi.org/10.5694/mja2.50545.

Australian Government (2020). The Alice Springs (Mparntwe) Declaration. Retrieved from https://docs.education.gov.au/ documents/alice-springs-mparntwe-education-declaration.

Ball, S. (1998). Big policies/small world: an introduction to international perspectives in education policy. Comparative Education, 34(2), 119-130.

Ball, S. (2012). Global Education Inc: new policy networks and the neoliberal imaginary. London: Routledge.

Bandura, A. (2006). Toward a psychology of human agency. Perspectives on Psychological Science, 1(2), 164-180. https://doi. org/10.1111/j.1745-6916.2006.00011.x.

Barnes, M., Moore, D., \& Almeida, S. (2018). Education for sustainability: a priority or an add-on? In M. Barnes, M. Gindidis, \& S. Phillipson (Eds.), Evidence-based learning and teaching: a look into Australian classrooms (pp. 179-189). Eng: Routledge, Abingdon. https://doi.org/10.4324/9781351129367.

Beckford, C., Jacobs, C., Williams, N., \& Nahdee, R. (2010). Aboriginal environmental wisdom, stewardship, and sustainability: lessons from the Walpole Island First Nations, Ontario, Canada. The Journal of Environmental Education, 41(4), 239-248. https://doi. org/10.1080/00958961003676314.

Board of Studies, NSW. (1998). Syllabus: human society and its environment $K-6$. Sydney: Board of Studies.

Bourne, D., Hunt, F., Bloom, N. (2016). Primary education for global learning and sustainability. Retrieved from https://www. researchgate.net/publication/296270870_Primary_education_for_ global learning and sustainability.

Buchanan, J. (2012). Sustainability education and teacher education: finding a natural habitat? Australian Journal of Environmental Education, 28(2), 108-124. Retrieved November 29, 2020, from http://www.jstor.org/stable/26422799

Buchanan, J., Aubusson, P. \& Schuck, S. (2014). A system-wide schoolbased program for sustainability: climate clever energy savers. In $\mathrm{K}$. Thomas \& H. Muga (Eds.). Handbook of research on pedagogical innovations for sustainable development. Pp. 245-269.

Buchanan, J. (2017). How do the standards stand up? Applying quality teacher frameworks to the Australian Professional Standards. In J. Nuttall, A. Kostogriz, M. Jones, \& J. Martin (Eds.), Teacher education policy and practice: evidence of impact, impact of evidence (pp. 115-128). Singapore: Springer.

Buchanan, J., Pressick-Kilborn, K., \& Maher, D. (2018). Promoting environmental education for primary school-aged students using digital technologies. EURASIA Journal of Mathematics, Science and Technology Education, 15(2).

Buchanan, J. (2020). Challenging the deprofessionalisation of teaching and teachers: claiming and acclaiming the profession. New York: Springer.

Cajete, G. (1994). Look to the mountain: an ecology of indigenous education. Skyland, NC: Kivaki Press.

Cars, M., \& West, E. E. (2015). Education for sustainable society: attainments and good practices in Sweden during the United Nations Decade for education for sustainable development (UNDESD). Environment, Development and Sustainability, 17, 1-21. https:// doi.org/10.1007/s10668-014-9537-6

Chapman, P. (2009). The benefits of green schools: the triple bottom line. Retrieved from https://www.invernessassociates.org/news/benefitsgreen-schools-triple-bottom-line.
Colvin, R., Ross, H., \& Baldwin, C. (2020). Social dimensions of energy system change in a disrupted world. Australasian Journal of Environmental Management, 27(2), 117-122. https://doi.org/10. 1080/14486563.2020.1768661.

Country, B., Wright, S., Suchet-Pearson, S., Lloyd, K., Burarrwanga, L., Ganambarr, R., et al. (2014). Working with and learning from Country: decentring human authority. Cultural Geographies, 22(2), 269-283. https://doi.org/10.1177/1474474014539248.

Department of Industry, Science, Energy and Resources (2020). Estimating greenhouse gas emissions from bushfires in Australia's temperate forests: focus on 2019-2020. Canberra: Australian Government.

Education Scotland (2020). Education for sustainability. Retrieved from https://education.gov.scot/education-scotland/scottish-educationsystem/policy-for-scottish-education/policy-drivers/learning-forsustainability/.

Evans, Whitehouse, \& Gooch. (2012). Barriers, successes and enabling practices of education for sustainability in Far North Queensland schools: a case study. The Journal of Environmental Education, 43(2), 121-138.

Fogarty, W., \& Schwab, R. (2012). Indigenous education: experiential learning and learning through Country. Canberra: Centre for Aboriginal Economic Policy Research, Australian National University College of Arts and Social Sciences.

Hall, N., Hicks, J., Lane, T., \& Wood, E. (2020). Planning to engage the community on renewables: insights from community engagement plans of the Australian wind industry. Australasian Journal of Environmental Management, 27(2), 123-136. https://doi.org/10. 1080/14486563.2019.1670742.

Hoekstra, A., \& Hung, P. (2005). Globalisation of water resources: international virtual water flows in relation to crop trade. Global Environmental Trade, 15(1), 45-56.

Jacobs, M. (1993). The green economy: environment, sustainable development, and the politics of the future. Vancouver: University of British Columbia Press.

Jackson-Barrett, E. M., \& Lee-Hammond, L. (2018). Strengthening identities and involvement of aboriginal children through learning on Country. Australian Journal of Teacher Education, 43(6). https:// doi.org/10.14221/ajte.2018v43n6.6.

Jóhannesson, I., Norðdahl, K., Óskarsdóddir, G., Pálsdóttir, A., \& Pétursdóttir, B. (2011). Curriculum analysis and education for sustainable development in Iceland. Environmental Education Research, 17(3), 375-391.

Jorgenson, S., Stephens, J., \& White, B. (2019). Environmental education in transition: a critical review of recent research on climate change and energy education. The Journal of Environmental Education, 50(3), 160-171.

Kennelly, J., Taylor, N., \& Serow, P. (2012). Education for sustainability and the Australian Curriculum. Australian Journal of Environmental Education, 27(2), 209-218. https://doi.org/10. 1375/ajee.27.2.209.

Ladson-Billings, G. (1992). Reading between the lines and beyond the pages: a culturally relevant approach to literacy teaching. Theory Into Practice, 31(4), 312-320.

Li, Y., Krasny, M., \& Russ, A. (2016). Interactive learning in an urban environmental education online course. Environmental Education Research, 22(1), 111-128. https://doi.org/10.1080/13504622.2014. 989961.

Lingard, B., \& Sellar, S. (2013). Globalization, edu-business and network governance: the policy sociology of Stephen J. Ball and rethinking policy analysis. London Review of Education, 11(3), 265-280.

Lockie, S. (2020). Sociological responses to the bushfire and climate crises. Environmental Sociology, 1(6), 1-5.

Louv, R. (2005). Last child in the woods. London: Atlantic Books. 
McCoy, K., Tuck, E., \& McKenzie, M. (2016). Land education: rethinking pedagogies of place from Indigenous, postcolonial, and decolonizing perspectives. London: Routledge.

MCEETYA (Ministerial Council in Education, Employment and Youth Affairs (2008)). Melbourne declaration on educational goals for young Australians.

McKenzie, M. (2012). Education for Y'all: Global neoliberalism and the case for a politics of scale in sustainability education policy. Policy Futures in Education, 10(2), 165-177. https://doi.org/10.2304/pfie. 2012.10.2.165.

Martin, S., Dillon, J., Higgins, P., Peters, C., \& Scott, W. (2013). Divergent evolution in education for sustainable development policy in the United Kingdom: current status, best practice, and opportunities for the future. Sustainability, 5, 1522-1544.

Ministry of Education [New Zealand] (n.d.-a). Education for sustainability: EfS in schools. Retrieved from https://nzcurriculum.tki.org.nz/ Curriculum-resources/Education-for-sustainability/EfS-in-schools.

Ministry of Education [New Zealand] (n.d.-b). Education for sustainability: learning experiences. Retrieved from https://nzcurriculum.tki. org.nz/Curriculum-resources/Education-for-sustainability/ Learning-experiences.

Ministry of Education [Sweden]. (2018). Curriculum for the compulsory school, preschool class and school-age educare (revised 2018). Stockholm: Norstedts Juridik kundservice.

Moore, J. (2005). Barriers and pathways to creating sustainability education programs: policy, rhetoric and reality. Environmental Education Research, 11(5), 537-555. https://doi.org/10.1080/ 13504620500169692.

Morgan, G., Tolhurst, K., Poynter, M., Cooper, N., McGuffog, T., Ryan, R., Wouters, M., Stephens, N., Black, P., Sheehan, D., Leeson, P., Whight, S., \& Davey, S. (2020). Prescribed burning in SouthEastern Australia: history and future directions. Australian Forestry, 83(1), 4-28. https://doi.org/10.1080/00049158.2020. 1739883.

Morgenstern, E. (2007). The origin and early application of the principle of sustainable forest management. The Forestry Chronicle, 83(4), 485-489. https://doi.org/10.5558/tfc83485-4.

NASA (2020). From smoke going around the world to aerosol levels, Nasa observes Australia's bushfires. Retrieved from https://www. nasa.gov/feature/goddard/2020/from-smoke-going-round-theworld-to-aerosol-levels-nasa-observes-australias-bushfires.

Nazir, J., Pedretti, E., Wallace, J., Montemurro, D., \& Inwood, H. (2009). Climate change and sustainable development: the response from education. The Canadian Perspective. Toronto: Centre for Science, Mathematics and Technology Education, Ontario Institute for Studies in Education, University of Toronto.

NESA (2019a). Geography outcomes. Retrieved from https:// educationstandards.nsw.edu.au/wps/portal/nesa/k-10/learningareas/hsie/geography-k-10/outcomes.

NESA (2019b). Geographical concepts. Retrieved from https:// educationstandards.nsw.edu.au/wps/portal/nesa/k-10/learningareas/hsie/geography-k-10/geographical-concepts.

NESA (2019c). Historical concepts and skills. Retrieved from https:// educationstandards.nsw.edu.au/wps/portal/nesa/k-10/learningareas/hsie/history-k-10/historical-concepts-and-skills.

Newmann, F., Bryk, A., \& Nagaoka, J. (2001). Authentic intellectual work and standardized tests: conflict or coexistence? Improving Chicago's schools. Chicago: Consortium on Chicago School Research.

Nowotny, J., et al. (2018). Towards global sustainability: education on environmentally clean energy technologies. Renewable and Sustainable Energy Reviews, 81(2), 2541-2551.

NSW Government (n.d.) Learning across the curriculum. Retrieved from https://education.nsw.gov.au/teaching-and-learning/curriculum/ learning-across-the-curriculum/sustainability/sustainability-actionprocessNWS
Ohara, M., \& Buchanan, J. (2018). English language teaching during Japan's Post-War occupation. London: Routledge.

Ojala, J. (2016). Facing climate anxiety in climate change education: from therapeutic practice to hopeful transgressive learning. Canadian Journal of Education, 21, 41-56.

Orr, D. (1998). Transformation or irrelevance: the challenge of academic planning for environmental education in the 21 st century. In P. Corcoran, J. Elder, \& R. Tchen (Eds.). Academic planning in college and university programs: proceedings of the 1998 Sanibel Symposium. Rock Spring, GA: North American Association for Environmental Education. pp. 1-12.

Ragusa, A., \& Bousfield, K. (2017). It's not the test, it's how it's used! Critical analysis of response to NAPLAN and MySchool Senate Inquiry. British Journal of Sociology of Education, 38(3), 265286. https://doi.org/10.1080/01425692.2015.1073100.

Roberts, P., \& Downes, N. (2016). Conflicting messages: sustainability and education for rural-regional sustainability. Rural Society, 25(1), $15-36$.

Sahlberg, P. (2012). How GERM is affcting schools around the world? Retrieved from https://pasisahlberg.com/text-test/.

Schuck, S., Aubusson, P., Burke, P., Buchanan, J. and Wei, E. (2016). Attracting teachers to rural and remote areas: a report to the NSW Department of Education and Training. New South Wales Department of Education, Sydney, Australia.

Shine, R. (2019). National school strike for climate sees students across the country planning to skip school. ABC News, (20 September 2019) Retrieved from https://www.abc.net.au/news/2019-09-20/ national-climate-strike-students-across-australia-skip-school/ 11528100 .

Smith, G., \& Stevenson, R. (2017). Sustaining education for sustainability in uncertain times. The Journal of Environmental Education, 48(2), 79-95.

Stevenson, R. (2007a). Schooling and environmental education: contradictions in purpose and practice. Environmental Education Research, 13(2), 139-153.

Stevenson, R. (2007b). Schooling and environmental/sustainability education: from discourses of policy and practice to discourses of professional learning. Environmental Education Research, 13(2), 265 285.

Strauss, A. \& Corbin, J. (1994). Grounded theory methodology: an overview. In N. K. Denzin, \& Y. S. Lincoln (Eds.). Handbook of Qualitative Research (Chapter 17, pp. 273-285). Thousand Oaks, CA: SAGE.

Taylor, N., Quinn, F., \& Eames, C. (2013). Educating for sustainability in primary schools. Rotterdam: Sense Publishers.

Tickamyer, A., Sherman, J., \& Warlick, J. (2017). Rural poverty in the United States. New York: Columbia University Press.

Tilbury, D. (1995). Environmental education for sustainability: defining the new focus of environmental education in the 1990s. Environmental Education Research, 1(2), 195-212. https://doi.org/ $10.1080 / 1350462950010206$.

Tsai, W. (2011). An investigation of Taiwan's education regulations and policies for pursuing environmental sustainability. International Journal of Educational Development, 32(2). https://doi.org/10. 1016/j.ijedudev.2011.06.003.

United Nations (n.d.). Sustainable Development Goals. Retrieved from https://www.un.org/sustainabledevelopment/sustainabledevelopment-goals/.

Wade, B., \& Griffiths, A. (2020). Examining best practice carbon management within Australian organisations: cases from contrasting sectors. Australasian Journal of Environmental Management, 27(2), 156-172. https://doi.org/10.1080/14486563.2020.1747029.

Wake, S., \& Eames, C. (2013). Developing an "ecology of learning" within a school sustainability co-design project with children in New Zealand. Local Environment, 18(3), 305-322. 
Whitehouse, H., Lui, F., Sellwood, J., Barrett, M., \& Chigeza, P. (2014). Sea country: navigating indigenous and colonial ontologies in Australian environmental education. Environmental Education Research, 20(1), 56-69. https://doi.org/10.1080/13504622.2013. 852655.

Wilson, S. (2012). Drivers and blockers: embedding education for sustainability (EfS) in primary teacher education. Australian Journal of Environmental Education, 28(1), 42-56.

World Bank (2020). Poverty. Retrieved from https://www.worldbank. org/en/topic/poverty/overview.
Yunkaporta, T. (2010). Our ways of learning in Aboriginal languages. In J. Hobson, K. Lowe, S. Poetsch, \& M. Walsh (Eds.). Re-awakening languages: theory and practice in the revitalisation of Australia's Indigenous languages. Pp. 37-49.

Zambrano-Monseratte, M., Auano, M., \& Sanchez-Alcaide, L. (2020). Indirect effects of COVID-19 on the environment. Science of the Total Environment, 728. https://doi.org/10.1016/j.scitotenv.2020. 138813.

Publisher's note Springer Nature remains neutral with regard to jurisdictional claims in published maps and institutional affiliations. 